\title{
XLIX. Remarks upon the inferior strata of the earth occurring in Lancashire: with some observations arising from the subject
}

\author{
Dr. Campbell
}

To cite this article: Dr. Campbell (1811) XLIX. Remarks upon the inferior strata of the earth occurring in Lancashire: with some observations arising from the subject , Philosophical Magazine Series 1, 38:162, 268-278, DOI: 10.1080/14786441108638645

To link to this article: http://dx.doi.org/10.1080/14786441108638645

曲 Published online: 27 Jul 2009.

Submit your article to this journal $₫$

Џll Article views: 3

Q View related articles $\sqsubset$ 


\section{Remarks upon the inferior Strata of the Eurth}

served a small black cloud very low, carried by a different current of air from the mass of clouds, from whence they imagined this stone to have proceeded: it flew with the greatest velncity over their heads, and fell in a field about three hundred yards from the house: they saw it fall. It was immediately dug up, and taken into the steward's office, where it remained two hours cooling before it could be handled. This account I have had from many who were present, and agree in the one story. I saw myself the hole the stone made in the ground; it was not more than a foot in depth. Should any thing further be wished for from me, I shall feel myself very happy in procuring from the men themselves their own account, and transmitting their own exact words and description to the Society.

$$
\begin{aligned}
& \text { "I "I am, sir, } \\
& \text { "13, Iower Mount-street, "Youry humble servant, } \\
& \text { May 22, 1811." }
\end{aligned}
$$

XLIX. Remarks upon the inferior Strata of the Earth occurring in Lancashire: with some Olservations arising from the Subject. By Dr. CAMPBELL, Kendal*.

7

THE subjoined article presents the reader with a new species of communication,-geological and mineralogical information illustrated with a coloured map. It was transmitted to the Bath Society by a highly respectable gentleman, Dr. Wilkinson, with a notification that Dr. Campbell, the author, was induced to write this essay, from observing the imperfect account of the stratification of Lancashire, by Holt $\uparrow$ and other agricultural writers. It were to be wished that the first specimen of the kind had been a geological account of the strata of Somersetshire, or some county comprehended in the title of the Society; but there is no doubt this example will be followed by others. Mr. W. Smith, a celebrated engineer, has arranged materials for a similar illustration of the counties conticuous to Bath; which, it is hoped, as soon as accomplished, will be sub. mitted to the public. The advantages to be derived from a plan of this kind, generally adopted, must be of considerable importance, both to the agriculturist and the miner.

The article is introduced in the volume from which we have copied it, with the following prefatory note:

* From Letters and Papers of the Bath and West of England Society, yol. xii. $\quad+$ John Holt's Agricultural Survey of Lancashire, 8vo, 1795 . 
" [We are obliged to the very ingenious Dr. Wilkinson for the following chart and description of the strata in the county of Lancaster; which, though it is a trespass upon our usual plan, we shall venture to insert in our Report without any other apology than the singular importance of the subject; and we earnestly recommend it to our correspondents to pursue a plan so happily begun. A similar history of the strata in all the counties of England would be an invaluable treasure. It would enable agriculturists, as well as geologists, to collect most important facts, and draw many practical inferences. They would learn with precision to adapt their crops to the nature of the soil ; and in many casez they would be able to ascertain whether a cheap corrective of any particular soil could not be procured, either at a moderate depth from its surface, or from lands that lie contiguous.-ED.']

LANCASHIRE appears to consist of a regular succession of strata of different kinds of rock which compose the lase (or, as it may be termed, the bone) of the country; whose respective limits may be ascertained with tolerable precision, and arranged in various districts. In these divisions of the country, although extreme accuracy cannot be expected, (from the rock of one division occasionally encroaching upon the limits of the other,) yet the general conclusions will be found to be just.

I. If you place before you a map of Lancashire, and draw a line nearly east and west through Cartmell and UIverstone, the whole district north of it is a mountainous country, whose rucky hills are universally of that kind of stone which is by naturalists denominated schistus; and from its component parts occurring in various proportions, has obtained the different names of slate, whinstone, blue rag, trapp, \&ce.

In this district there is neither freestone nor limestone, except a vein of the latter which lies in a crack or fissure of the blue rocks, (by miners termed a dyke), and runs across the country from east to west, near Connistone Fells.

II. If another line be drawn nearly parallel to the former, a few miles north of Lancaster, the base of the whole district included betwixt them is limestone, immense rocks of which raise their gray beads above the fertile land at their feet. Such are Warton Cragg, Hampsfield Fell, and the rocks of Silverdale and Kellet. Larce blocks of granite, mostly of a round form, are frequently to be met with on the surface of the earth in the limestone (and perhaps in 


\section{Remarks upon the inferior Strata of the Earth}

the bluestone) district: although there be no rock of this species that I know of in the country*. They have the appearance of having bad their edges broken away, and rounded by attrition, like the smaller pebbles.

This mass of limestone runs away to the north, as far as Kendal, and eastward by Farlton-Knot, Hutton-Roof, and Kirkby-Lonsdale, towards Settle and Skipton in Yorkshire, and skirting Lancashire, comes into it again about Chipping and Clitheroe.

III. This limestone district ceases about five miles north of Lancaster, and gives way to another arrangement, viz. of shale (or shivert) and freestone. But as freestone is an ambiguous term, arising merely from the facility, with which a stone can be wrought by the tool, and is applicable to stones of very different qualities, it will perhaps be better to distinguish the particular kind 'occurring here by $\mathbf{M r}$. Whitehurst's denomination of millstone grit; being, like that which he notices in Derbyshire and other places, composed principally of quartz pebbles (a species of flint) and mica.

From this part of the country about Kellet, to as far south as a line drawn from the vicinity of Colne towards Blackburne and Chorley, and so on to the westward, the base of the country is millstone grit, mostly incumbent on shale.

In some places, (such as Grassyard woods and Ravenscar, about five miles from Lancaster, ) and near Catshaw Factory in Wyresdale, this arrangement of the gritstone resting on immense beds of shale is evident. In other places it is not so easy to be ascertained, as, the incumbent stratum of gritstone having been destroyed, the shale appears on the surface of the earth, or the grit rock has not been penetrated deep enough to arrive at the shale. Finally, the beds of shale differ in thickness, and are in some instances, perhaps, totally wanting.

IV. After proceeding as far south as Chorley and Burnley, the primitive strata change to a soft argillaceous sandy stone, containing no quartz pebbles. Such are the inferior strata which form the base of the country in each of these districts; and which have considerable influence on the incumbent soil, and its productions; which we shall proceed to notice.

I. The district of Schistus, or Blue Rock.

The summits of the highest mountains of Furness must,

* The nearest granite rock is on the west side of the road from Kendal to Shap rear the twelfth mile-stone. and.

t Shale (or shiver) appears to consist of indurated clay, mica, and a little 
from their great heights and rocky natures, ever remain in a sterile state; but yet grass grows, and sheep pastures extend to the tops of many of considerable altitude. Where they are of a lower or secondary order, they are capable of being covered with wood, which grows freely. This kind of rock being of a fissile nature, and composed of laminas or layers, mostly arranged so nearly perpeudicular as to form an angle of about 90 with the horizon, the roots of trees find a passage for their small fibres to insinuate themselves betwixt them, and thus obtain a ready vegetation on the almost naked stones. Most of the woods with which that country abounds growing upon rocky ground, where nothing else would be produced, but which flourish there spontaneously, if only fenced from cattle *; thousands of acres that would be absolutely useless under any other culture, are by this means rendered highly beneficial. The woods are in general cut every fifteen or sixteen years, and the crop is reckoned of the same value as the land. For instance, if the cutting, or fall, (as it is here termed,) be worth $16 l$. and the land were to be sold immediately after, it would be estimated at the same sum.

Exclusive of what comes under the denomination of timber, these woods are converted to many uses; particularly into charcoal, for smelting the iron ore from Low Furness, in the many furnaces dispersed over the country for that purpose. Poles for hoops, and the seemingly insignificant article of birch besoms, are obtained from these woods in great quantities. Bird-lime is also manufactured from the bark of the holly, which abounds in the country, and is principally exported to the. West-Indies for the destruction of insects.

These woods contain all the varicty of trees natural to the kingdom, but they consist mostly of oak and ash. Hazles grow in great abundance in the country north of Lancaster; insomuch that it was computed that upwards of $1000 l$. worth of nuts were sold there at the last Michaelmas fair, principally bought for the Manchester and Liverpool markets.

Immediately incumbent on the rocks generally lie beds of what in this country is called sammel, (rubble,) which is the rocky matter broken down into small particles, and forming a compact bed of a particular kind of gravel. This furnishes most excellent materials for the roads, for which the whole of this district is so justly celebrated. With

* Mr. Holt, in the Agricultural Survey of Lancashire, states, that " there are no natural woods in the county." 


\section{Remarks upon the inferior Strata of the Earth}

scarcely a turnpike-gate in the country, they resemble more the walks in a garden or a pleasure-ground than a highway.

This mass of sammel is covered by the soil of the country, generally a light hazle mould, produced by the remains of decayed vegetables, and what manure has been added by culture. It is however in general thin and stony. Some idea may be formed of its nature, by observing the brook and rivers after the heaviest and longest continued rains. They are augmented in bulk, but no alteration takes place in their transparency: clear as crystal, the smallest pebble may be still seen in their bottoms.

The lower grounds are fertile, and the frequent showers which are attracted by the lofty mountains contribute much to the growth of wood and grass, but render it less eligible as a corn country.

No marl is found in this district; consequently the system of manuring is reduced to lime, dung, and the ashe of turf and peat, (the principal fuel of the country, found to be a great fertilizer. Lime is expensive, as the coals with which it is burned must be fetched from a distance of more than twenty miles by land carriage, or obtained by shipping at the rate of 25s. per ton. But where it has been used, it has been spoken of as highily advantageous in improving both the quantity and quality of the grass.

A coarse clay is found in some places, which has been spread with advantage upon the meadow land, improving the soil by giving it a consistency which enables it the better to retain the manure that may be spread upon it.

A copper mine has been worked at intervals for many centuries in the mountains at the head of Connistone Lake: at present it is discontinued, although lately in the bands of some spirited and intelligent adventurers.

Some of the most considerable quarries of blue slate in the kingdom are in this district. It is found in various places in the mountains, and brought down partly by land and partly by water carriage, and shipped either at PennyBridge or in the river Dudden.

II. On entering the limestone district, a remarkable difference may be observed in the form of the summits of the mountains; those in that which we have just quitted having a sharp serrated outline; while the limestone rocks, lying mostly in horizontal strata, have one that is flatter and smoother, with generally a precipice on one of the sides; and being of a more compact structure, they do not. so readily admit the roots of trees to insinuate themselves 
inlo the mass, as happens with respect to the blue rock. The summits of the higher limestone rocks are mostly destitute of soil, and exbibit a desolate prospect. Fragments of the limestone rocks cover the ground to a great depth below the abrupt faces of these mountains; and the valleys are filled up by a calcareous sammel, forming a very compact body similar to that formerly mentioned, (p. 271 ) or by the limestone fragments rounded by attrition into the form of pebbles, and mixed with others of whinstone, granite, and gritstone.

The interstices of these pebbles are frequently filled to a considerable depth with a fine mould; so that although the ground may at first sight appear so stony that lintle vegetation could be expected; yet, under proper management, excellent crops are produced $*$.

The soil is in general a brown or bazel mould, rather light, but capable of being made productive of the finest grass by the addition of the usual manures. All the poas and white clover are its natural tenants. Rushes, except on the mosses, are rarely seen in this district. A small addition of clay, or argillaceous matter, appears capable of giving it that kind of tenacity which would enable it better to retain any manure which might be spread upon or incorporated with it.

Marl, but especially shell marl, is found in sufficient quantity in Low Furness, and has been used with success as a manure in particular instances. It has not, however, become a general practice, although it promises to be of the highest utility. A proportion of clay has lately been discovered in some of the beds of sammel, which of course constitutes marl; and its effects on the adjoining lands will probably be soon put to the trial.

The west of Ulverstone (which is called Low Furness) is a fine champaign country, with little wood, and forms a perfect contrast with the mountainous district to the northwest of it, and is extremely fertile both in arable and pasture ground. From the comparative lowness of the land, the clouds frequently pass over it without depositing their contents, until they are attracted and stopped by the lofty

* In cutting the various canals in this country, a very accurate discovery of the nature and quality of the soil has been made, trequently to a considerable depth; and ir appears surprising how thin a stratum of mould on the surface is frequently adequate not only to the mere purposes of vegetation, but to the production of good crops both of grass and corn. In m.1.y instances a few inches in thickness of mould are incumbent on immense beds of the most sterile flinty gravel, in a part of the country where this land lets for $5 l$. per acre, (customary measure.)

Fol, 38. No.162. Oct. 1811 .

hill $_{\mathbb{S}}$ 


\section{Remarks upon the inferior Strata of the Earth}

hills in the interior part of the country; where it happens to be no uncommon circumistance that there is fine weather in Low Furness, whilst they are deluged with rain in the mountains.

A red freestone, composed mostly of fine sand and mica, is fonnd to the west of Ulverstone: and a quarry of excellent millstone grit near Holker, immediately incumbent on the limestone.

Great quantities of iron ore are raised a few miles to the westward of Ulverstone, but principally at Whitridge, (which West, in his Antiquities of Furness, calls the Perns of that country.) It is found beneath the limestone rock, not in veins but masses; uncertain as to extent, and hence attended with the usual disadvantages incident to mining concerns : it is of the species called by naturatists hcematites or kidney ore, (from its resemblance to the kidneys of certain: animals.) There are three distinct species found in these mines. The account given by $W$ est is as follows : "Iron ore is found at the depth of from twenty to thirty yards : it is raised at $3 s .6 d$. and $4 s$. per ton, and pays $1 s .6 d$. per tor to the lord of the soil. It is carted and put on board vessels for exportation at $3 s$. and sells from $11 s$. to 12s. per ton. Great quantities of lapis hamatites are raised with the ore of Whitridge, which the workmen call kidney and steel ore:common ore.

"First. The lapis hematite, loltriodes, or glelnsas.

"Secnnd. The convolved kind, described by Aldrovandus and Imperiali : it is the richest ore, and easily distinguished from the rulrica falrilis, commonly called ruddle.

"There are other works of the same kind in Furness *."

This ore is of a very greasy and defiling nature, as Mr. Pennant has justly observed, marking every thing it touches with a red stain. The iron produced from it is of the toughest kind, and much valued where that quality is required. It is smelted rot only in the furnaces dispersed over the neighbouring country, but exported in great quantities to Scotland and Wales. These mines are of great antiquity, having been worked upwards of 400 years.

Copper ore has been discovered in the rocks at Yealand and Warton, and the veins pursued at a considerable expense; but proving so thin as not to repay the cost, they are at present abandoned.

What is the base of Walney Island, is, I believe, not

* Antiguities of Furness, p, 17.

ascertained. 
ascertained. West speaks of it thus: "Walney Island lies upon a bed of moss; and all round the island moss is found by digging through a layer of sand and clay which covers it ; and in the moss large trees have been found." It is probable, however, as limestone rocks are observed in the adjacent sands, that these extend below this island also.

In common with other limestone countries, there are many subterraneous excavations of considerable extent, such as Dunald mill Hell-hole, near Kellet, Yardhouse-cave, near Leck, and other smaller ones near Yealand.

III. The district of millstoue grit and shale contains almost every possible variety of soil and situation.

To the north and east, lofty mountains form moors covered with ling, which stretch away from the neighbourhood of Hornby, by Wyresdale, towards Rivington Pike. The western part is an uniform flat; and the intermediate country possesses the champaign properties that lie betwixt these two extremes.

The grit rock being almost entireiy a finty substance, its broken-down particles are of all others the least favourable to vegetation. Hence we find that where the rock is merely covered with a gravel composed of such fragments, (which is mostly the case on the high lands towards the moors,) ling, the hardiest of vegetables, can only find a footing; and the scanty soil produced by its decayed remains in the course of centuries, attests the slow progress of vegetation.

Planting with the hardier kinds of trees is perhaps the only improvement this kind of land admits. But it is a point not yet ascertained, at how great a height above the sea trees capable of producing timber will flourish in this country. At cousiderable altitudes they become dwarfish, and affect the form rather of the bush than the tree.

Where circumstances more favourable for the retention of moisture occur, mosses have been found, which being drained afford a considerable depth of a loose black soil. In many parts, at the foot of the mountains, the whole cultivated country appears to have been originally of this nature, and, being of a spongy texture, is capable of retaining mois:ture long; and bence, notwithstanding the looseness and lightness which it exhibits under the plutgh, when allowed to remain in pasture a few years it is apt to be overrun with rushes.

It frequently happens that a coarse clay covers the tops and sides of the hills and moor lands which are of a secondary height, whicil preventing the rain, or the water \$2 which 


\section{Remarks upon the inferior Strata of the Earth}

which flows from the higher grounds, from penetrating beyond a certain depth, such land is oveigrown with moss and rushes, forming a perfect sponge, and affording scarcely any vegetation useful for pasturage. But from what has been done to particular spots in the vicinity of this mossy land, we see that by draining, and the usual modes of improvement, such lands are capable of being made very beneficial.

Where, instead of the grit rock, the shale occurs on the surface of the ground, a considerable change may be perceived in the nature and appearance of the vegetables produced ; and this latter, being a particular kind of indurated clay, is easily convertible into excellent soil.

A striking contrast offers itself betwixt the appearance of the vegetation on the mountains and hilly grounds in this district, and that of limestone. Here, they are mostly covered with ling, rushes, and moss ; there, such productions are scarcely seen; whilst the finest kinds of grass and white clover cover their sides, and are found in the interstices of the rocks to their very summits. The same difference is observable upon passing through this mass of moor land into the limestone country in Yorkshire, which lies to the eastward. This change appears to be occasioned, as weil from the decayed particles of the limestone rocks being naturally disposed to furnish a soil more favourable to the growth of nutritious grasses, as from the water and rain finding a more ready passage into the earth, in consequence of not meeting with beds of clay and marl beneath the surface.

In the lower grounds the top monld is mostly of a fine quality. A few miles to the north of Lancaster, the earth begins to have a considerable mixture of clay and marl in its composition, which continues more or less through the whole country to the southward, intermixed with extensive beds of gravel and sand. But from about five miles south of Lancaster the general mass of the country in the lower grounds is, upon digging a few feet, found to be almost entirely manl or clay, incumbent upon the rock or shale which form the basis of the district.

Where these beds of gravel occur, the top soil is in general thin, and requires frequent repetitions of manure to keep it in good condition. Where there is clay and mant beneath, it is generally of an excellent quality, but subject to the common inconvenience of this kind of substratum, the copious growth of rushes.

There is also in this district a considerable quantity of 
moss land, which lies principally to the west of Garstang, a part of which is annually reclaimed, and converted into ground which produces good crops of corn*.

Besides the common manures, a great part of this district has also the advautage of both mart and lime, and is hence capable of being put into the highest state of cultivation. The parts of the country bordering upon the Bay of Morecombe have also two other kinds of local manures, viz. muscles and sand. The muscles are found in immense beds, which are accessible during the tide of ebb, and they are then carted away in great quantities for this purpose. They are, however, said to be a manure whose good effect are not more durable than a single year. The sand procured upon the coast fifom the nature of its component parts) has not only been found advantageous to the stiffer clay lands, but also to those of a lighter texture. Besides the flinty particles usually found in sand, a great proportion of what is got here consists of particles of shells minutely divided, and is hence of a calcareous nature: a portion of clay is also mixed with it, which with some seasalt $t$, and the remains of decayed animal and vegetable matters, form altogether a substance very different from common sand.

Some iron-stone is found in the shale. This district, however, is not productive of any ores which have been wrought $f$. The stone which occurs here is however extremely valuable for a variety of purposes. That which is gotten in the neighbourhood of Lancaster, and in Whittle Hills, is of the most valuable kind of freestone; and blocks of almost any size may be procured. From the great quantity of quartz or finty particles which enter into its composition, the durability will probably be nearly equal to that of granite, Millstones of an excellent quality are gotten in Whittle Hills, and from Kellet Moor; and a fine kind of

* By means of marl, which is generally found beneath the moss, and by parizy and burning, which, although disapproved by lord Dundonald, is here the source of abundant fertility; there being no fear of exhausting the vegetable matter by this process. A particular kind of clogs, called moss pattens, are affixed to the hinder feet of the horses emplnyed in ploughing, which prevents them from sinking into the ground, which is frequently so soft as not to be accessible without such assistance.

+ When the tide retires, it leaves many miles of these sands dry; and in the summer season the evaporation being considerable, a white crust or pellicle of salt is formed on the surface, from which culinary salt was formerly obtained, by collecting the sand containing this pellicle, and, after dissolving the saline particles in sea water, evaporating the brine, thus made, in pans.

† There is some lead ore in Anglezark, belonging to eir F. Scacdisb; and carbonate of barytes. 
flags and whetstones from Hutton-Roof, about six miles north-east from Lancaster.

There is a thin seam of coals, which apparently originating in a valuable but limited colliery near Ingleton in Yorkshire, extends by Hornby to within a few miles of Lancaster, when it lassets, (in the language of miners,) or runs out upon the common above the town. It is not found in a stratum of argillaceous stone, but (contrary to what occurs in this comntry, and in general in this kingdom) in a most compact quartzose or flinty one; the particles of which are so compact and hard, as not only to strike fire with steel, but to be almost inaccessible to the tool.

\section{On Smelting of Lead. By Mr. John SAdLER*.}

Dear Srr, Most of the lead of commerce is obtained from that species of ore which is by mineralogists called galena, potter's ore, or sulphuret of lead. Indeed, it is the only species of lead ore which is found in sufficient quantities to be worth working.

There are many other species of lead ore met with nccasionally; but these, occurring but seldom, are regarded as curiosities, and are generally carefully selected for the cabinet of the mineralogist, or as ornaments for the mantlepiece of the miner.

The ore, as it is first raised from the mine, is mixed with a considerable proportion of the matrix or gangue of the vein, from which it must be in great measure freed before it is fit for the operation of smelting.

For this purpose, the ore is delivered to the dressers, who either break it into small pieces with hand-hammers of a peculiar construction, which are called buckers, or it is passed between rollers worked by machincry, or under stampers. It then undergoes the operation of washing, to separate it from the lighter foreign matter, after which it is ready for the smelter.

\section{Construction of the Ore Hearth.}

The smelting of lead is performed differently in different districts. In inost parts of the North, particularly in Cumberlaisl, Durham, and Northumberland, smelting is performed in the ore hearth by means of bellows. In some parts of Yorkshire, in Derbyshire, and in North Wales, lead

* From Clennell's New Agricultural and Commercial Magazine. 